\title{
THE MEDIA AND ELECTORAL POLITICS IN LESOTHO BETWEEN 1993 AND 2007
}

\author{
Nthakeng Pheello Selinyane
}

\author{
Nthakeng Selinyane is a lecturer in the Department of Political and \\ Administrative Studies, National University of Lesotho \\ Tel: +26622213 737/22340 601; Fax: +26622340000 \\ e-mail: nthakeng@yahoo.com
}

\begin{abstract}
It has become commonplace to lambaste the media for its failure to play a positive role in the cause of nation-building and democratisation and (Southern) Africa is no exception to this trend. Little effort, if any, however, has gone into examining the reasons for the stance taken by the media. Nor has any effort - save for various attempts to bribe, cajole, persecute or suppress - gone into mapping the role of the media in Lesotho's electoral politics since the reversion to competitive multiparty constitutionalism. This paper is a preliminary attempt to fill this vacuum.
\end{abstract}

\section{INTRODUCTION}

The discussion is divided into five parts: why is it logical to discuss the media in tandem with electoral politics? What are the prevailing perspectives on the social and political roles of the media? How have the media intervened in shaping the debates about democracy and the democratic landscape of Lesotho since the transition of the late 1980s? What role has the media played specifically in relation to the election process? The final section ties together the general observations of the paper and makes tentative suggestions about the way forward.

\section{LEGITIMATE ENTRY POINTS FOR MEDIA IN THE DISCOURSE OF ELECTORAL POLITICS}

I consider the media to be part of civil society and to occupy the same position assigned civil society in contemporary discourses of democracy and good governance. This is a provocative assertion, for it is widely accepted that there is 
no consensus about the definition of civil society and its place and function in the democratic project.

Among the areas of contention are whether civil society should be seen as comprising all organised life between the family and the state; whether it should be separated from political society or be subsumed by it; whether it should be organised and self-representing or whether each individual entity should be considered deserving of the label as long as it is outside the state. Allen (1997) and Osaghae (1997), among others, believe civil society is nebulous and of little use, while others see it as a way for society to restrain (potentially) repressive states (Harberson, Rothchild \& Chazan 1994; Ndegwa 1996; Bratton 1989).

The various opinions of good governance and democracy alluded to above place their central thrust on precepts of participation, respect for the client, and responsiveness to those whom the bearers of public office are supposed to serve. In this connection two important points can usefully be made: one is that the media, like civil society, of which I contend they are a part, cannot be expected to be of any one complexion but are as perverse or virtuous as the various shades of civil society.

Secondly, the enforcement of these precepts must start with the laying of foundations, that is, if the media fail to ensure that the constitution of government through national elections is undertaken in observance of those ideals it is likely to be that much harder to rein in the wayward role players once the government is in place. As an element of civil society the media in Lesotho are enabled to undertake this task by the following instruments and frameworks which assign civil society a role in national and regional affairs:

- The Lesotho National Vision 2020, especially, but not only, the sections that speak to the imperative of having in place a stable democracy at peace with itself and with its neighbours.

- The Lesotho National Goals and Objectives, and the Smart Partnership compact.

- The Southern African Development Community (SADC) Treaty, especially Chapter Four on Operational Principles, which stipulates that SADC members should be guided by norms of democracy, human rights, and the rule of law; read together with the provision that all disputes should be resolved amicably. In addition, the 2001 amendment, which goes further than the 1992 text, includes nongovernmental organisations (NGOs), civil society, and business and workers' organisations as official stakeholders in the business of SADC and incorporates them into SADC business at national level via the SADC national committees. 
- The SADC Parliamentary Forum's treatise on Norms and Standards for Elections in the SADC Region, section 8 of which stipulates unambiguously that 'the media plays an important role in terms of fostering the integrity and transparency of the Electoral Commissions and on building public confidence. Therefore, the Electoral Commissions and the media should view themselves as allies and not as adversaries in the institutionalisation of the democratic process in the conduct of elections' ( $\mathrm{p} 21$ ).

- The African Union's (AU) Economic Social and Cultural Council (ECOSOCC), which makes it mandatory for representatives of civil society to be included in the prosecution of AU business at the national level, and provides for observer representation of civil society at some AU meetings.

\section{PERSPECTIVES ON THE SOCIAL AND POLITICAL ROLES OF THE MEDIA}

There are several views on the role of the media in society. Four main threads merit attention: The libertarian version holds that the government has no right to interfere with the media; that individual citizens are mature and rational enough to distinguish right from wrong in the messages of the media and that the media have the right to be left alone in their search for the truth and market forces will dictate what appeals to the tastes and sensibilities of the consumer.

The authoritarian view holds that the role of the media is to serve a people through its chosen government and to disseminate the information the rulers want to pass on. The media must make no effort to turn over stones and search for information.

The egalitarian paradigm is close to the libertarian view, but emphasises the rights of communities as opposed to individuals. The media should reflect the views of all segments of society and no group should monopolise the media and gain unfair advantage in the contest for control of resources or influence over the thinking of fellow community members.

The developmental perspective arose in tandem with mainstream developmentalist discourse in the post-war world. This view holds that the media complement other instruments in the arsenal necessary for the attainment of national development and social engineering. The state must be in a position to mobilise the media to throw its weight behind a number of national initiatives (Keane 1992; Curran 1991a).

Political theories about the media run along roughly the same lines as the social perspectives. They are generally grouped into three broad areas, namely, 
the media should: inform citizens about events in the community, educating them via interpretation of the information, its implications and significance; provide a public political discourse forum; and throw light on the abuses perpetrated or occurring within governmental and political institutions - the watchdog function. The media are further expected to provide an outlet for advocacy which may go further in the direction of persuasion, or endorsement of certain parties or candidates (Ronning 1993; Curran 1991b; Murdoch 1992).

\section{THE MEDIA AND THE ‘CRISIS’ OF DEMOCRACY IN LESOTHO}

In the past two decades of transition to multiparty electoral politics it has become customary to use the word 'crisis' to describe political developments in Lesotho. Such fashionable phrases have traditionally been disseminated through the media, especially the private newspapers. The media are very powerful in Lesotho. This is especially true of the oldest (church-owned) newspapers, Leselinyana la Lesotho and Moeletsi oa Basotho.

The media's influence in shaping the public's views of democracy has been equally important given their freedom to choose either to put forward their own line or to reproduce and popularise that of a particular political party. The role of the press in propagating democratic ideals of tolerance and respect for the Constitution, truth rather than falsehood, civil debate rather than name-calling and slander, reconciliation, and integrity in national government, has been, at best, inconsistent.

The media have made their own rules and adjudicated their enforcement and observance; they have moved the goalposts when they have acted with dubious integrity, and there has been no one to rein in the media's contribution to what they like to call the 'crisis' in Lesotho's democracy. The following section throws light on some prominent incidents.

The almost unanimous actions of the mainstream media in exhorting the electorate to ignore certain political parties and focus only on the formerly incumbent Basotho National Party (BNP) and the formerly exiled Basutho Congress Party (BCP) in the 1993 general elections was widely noted.

Leselinyana la Lesotho, for instance, in an editorial (13 December 1991) condemned the formation of new parties as a malicious attempt to make certain main parties lose the elections.

Immediately after the BCP's one-party National Assembly was established in 1993 the fervour with which some newspapers had argued for a two-party legislature began to diminish and they openly backed the one-party state.

In the months and years that followed the media began to diverge in their commentary on the unfolding record of the government. Increasingly the Catholic- 
owned Moeletsi oa Basotho revelled in the problems of the BCP government, especially the intractable Lesotho Liberation Army (LLA) integration question, and the army, police and prison warder strikes and mutinies.

At the other extreme was the grandiloquent pro-BCP tabloid, MoAfrika, which seemed to thrive on sensational rumour-mongering and the vilification of individual politicians both in and out of government, within and beyond the fold of the BCP.

When, in December 1996, the faction of the BCP leadership the newspaper had defended in 1994 declared that it intended to stay in office indefinitely, and denounced the government's commitment to the formation of an Independent Electoral Commission (IEC) to administer the coming general election, MoAfrika applauded. While most of the BCP government's problems were manufactured within the party the media reports either whitewashed the $\mathrm{BCP}$ and hurled thinly disguised vituperation at the institutions of government and the political opposition (in the case of MoaAfrika) or fuelled political intolerance of the government, and even lauded those who overtly sought to topple it (in the case of Moeletsi oa Basotho).

While remaining on the side of those media that defended the government at all costs the Protestant Leselinyana la Lesotho was of a less fundamentalist persuasion. Moeletsi oa Basotho reported on the BNP leadership's calls for mutiny by the army while throwing fuel on the smouldering government-army standoff.

Commenting on the king's long-running feud with State House the paper stated (17 April 1994) 'He who appeals to democracy to solve his problems may find himself longing for the days of the past [ie, repressive rule]. This was clearly an appeal to the conflicting parties to look beyond democratic structures for solutions to their problems.

Editorials in Moeletsi oa Basotho increasingly called on the government to step down (see 11 June and 1 October 1995). Most observers would be adamant that journalists should not be prevented from exercising their freedom either as citizens or as professionals, but, at this time, the exploitation of these freedoms was being used mainly in ways that were far from constructive, especially given the long tunnel of uncertainty, disunity, reprisals, and mutual suspicion from which Lesotho was emerging as a nation.

The events following the brief removal of the BCP government in August 1994 were equally revealing of this weakness of the independent media. The BCP emerged from the 'palace coup' more repressive and arrogant than ever. The spate of undemocratic legislation and the pace at which anti-democratic and selfserving policies were implemented was indicative of an uncertain group which wanted to make hay of accumulation for as long as the sun shone. To their credit the private media across the spectrum consistently reported on these develop- 
ments - the teachers' strike of 1994/95; the Public Service Act of 1995, which suppressed the civil service; the largely unpopular Education Bill of 1995; the Privatisation Act of 1996; the Pardons Act of 1996; and so on.

While differences in perspective are welcome in any democratic dispensation it is another matter to call for the government to be brought down in the process of promoting one's view. This is essentially what MoAfrika, with its regular barrage of vitriol, did repeatedly with respect to the Pardons Act, for example. This type of reporting did little to strengthen democracy or the culture of tolerance on either side.

In the period under review the mainstream print media also did little to deter the extra-parliamentary subversion of democracy. To the extent that street marches calling for the dissolution of the government were hailed by the media as acts of bravery (as long as they were anti-BCP/Majelathoko), this largely distracted attention from the absolute imperative to build a broad social base for opposition politics by mobilising around issues of importance to the nation's development. Indeed, after the BCP split in June 1997 both Moeletsi oa Basotho and MoAfrika supported extra-parliamentary plans to rock democracy by mobilising the masses against the government or by calling for a coup. Citizens were urged to march in support of moves to challenge the alleged violation of the Constitution. The king and the army were exhorted to replace the newly formed LCD government with a coalition government pending a new general election.

The two newspapers also derided the steps towards the formation of the IEC. On this point they were both true to their disparaging and denigrating stance on the subject and complacently emphasised the 'fact' that the 'big' parties rejected the installation of the IEC under the LCD government and that this rejection spelt doom for the next general election.

The focus was not on whether this was a socially beneficial, principled stance. The papers called for a military coup or, alternatively, a 'palace coup' similar to the one the BCP had survived in 1994 thanks to the concerted efforts of civil society and regional shuttle diplomacy (Selinyane 1997a, b).

At the other end of the spectrum Leselinyana la Lesotho veered between heartbreak and rage at Prime Minister Ntsu Mokhehle's breakaway from the BCP. At one point the paper condemned the LCD's birth and assumption of the mantle of government and regretted that Mokhehle was still in office despite his declared intention to retire.

At another point the paper evoked the scriptures to portray the formation of the LCD as an omen that the end of the world was nigh (editorial 26 June 1997). For these shepherds of democracy emotional outbursts prevailed over the duty to learn, understand, and teach readers how Lesotho's democracy works. The psychological crises of individual editors and owner-publishers were elevated to 
a national 'crisis of democracy'. Only the private English-language media (Mopheme and The Mirror) stood resolutely on the sidelines in their reportage.

It would be naïve to expect all media to support one particular cause at any one time (the media represent a spectrum of opinion), but it may be considered excessive for sections of the media to arrogate to themselves the status of defender and missionary of democracy, and simultaneously champion some of the more bizarre anti-democratic tendencies. Lesotho has reached a point in its history when strong, conscientious, honest and objective media should be among the essential pillars of national democracy.

\section{CONCLUSION}

The private press in Lesotho has been in existence since 1863, while private radio dates back only 10 years, to 1998. A total of nine newspapers and six radio stations were surveyed to gauge the performance of the media during the elections of 1998, 2002, and 2007. Seven indices were employed for this purpose:

- Openness to diverse opinion: Do news pages/bulletins and letters/ commentary sections reflect a wide spectrum of public opinion?

- Balance of coverage: Are the agendas of all parties, big and small, accommodated in the news?

- Equity of coverage: Is equal emphasis placed on the opinions and views of all parties?

- Contribution to peace-building: Is the tone of reporting tolerant or belligerent?

- Level of advocacy: Do the media make an effort to lobby their audience/ readers to take a specific stand?

- Voter/civic education.

- Encouragement to vote.

The picture that emerges can be thus summarised:

Those media houses which show a greater openness to various opinion trends tend to carry more balanced and equitable coverage while those which are less open are more inclined to advocacy. The more open media tend to advocate principles while the others advocate regime change without reference to principles.

The Sesotho-language newspapers tend to carry a narrower range of opinions than their English-language counterparts. There seems to be a clearer propensity for endorsement in the former than in the latter.

Openness to diverse opinions grows over time in the English press, but there is little noticeable change in the Sesotho press. This remains true regardless of 
whether the Sesotho press is privately owned or owned by established religious denominations. Both English and Sesotho newspapers had a lacklustre approach to voter education.

After the watershed elections of May 1998 there was a perceptible change in the tendencies of the press, which showed greater openness and more of an inclination to contribute to peace building and to encourage a high voter turnout. By and large the tone was less strident and divisive and there is a greater tendency to preach the values of mutual accommodation, commitment to agreements, and national dialogue.

The entry of radio after the 1998 general election marks an interesting change in the media's influence on politics in general and elections in particular. Radio scored better than the print media in the areas of election coverage and civic education because it was able to host activists and technocrats from civil society and the IEC, which the space constraints of the press largely do not permit. Only a few radio stations, however, made a deliberate effort to initiate and mount voter education programmes - MoAfrika FM was the best of these.

It is important to investigate the track record of the media as far back as possible in order to understand current trends.

The earliest press was pioneered by the colonial state and missionaries and the earliest privately-owned press was effectively a protest/resistance press. Religion and politics have always informed the press, even in post-colonial times. Most private radio stations in Maseru have pretensions to being religious, while evincing deeply partisan political leanings.

\section{RECOMMENDATIONS}

Measures for building on the strengths and weeding out the weaknesses noted above may include the following:

- Giving the media a central role in the election processes, not merely for purposes of 'teaching' them how to report properly on elections. For instance, the media were excluded from the mediation sessions led by Sir Ketumile Masire in efforts to resolve the post-election conflicts which meant their only resort was to speculate about the process.

- Assisting in the creation of independent self-regulating media institutions which will encourage the media to observe a common ethos and subscribe to a voluntary code of practice in respect of election processes and accompanying national endeavours. 
- Ensuring that national political, religious, and industrial (workers and business alike) elites observe and uphold national values. It is not a defence of the media to suggest that if the various enabling institutions cited above are not sustained by the nation's leaders the media can hardly be expected to volunteer itself for the role.

- Heeding the voice of the media when they offer constructive criticism and creative suggestions for problem solving and institution building. The media can provide a fertile hunting ground for solutions to many challenges, not as much because of the ingenuity of their editorial staff but because of the access they provide to a wide range of public opinion.

- Establishing an independent media standards authority which can judge impartially the propriety of the conduct of the various participants.

\section{- REFERENCES}

Allen, C. 1997. 'Who Needs Civil Society?' Review of African Political Economy 73.

Bratton, M. 1989. 'Beyond the State: Civil Society and Associational Life in Africa'. World Politics 41(3).

Harbeson, J W, D Rothchild \& N Chazan (eds). 1994. Civil Society and the State in Africa. Boulder \& London: Lynne Reiner.

Curran, J. 1991a. 'Rethinking the Media as a Public Sphere'. In P Dahlgren \& C Sparks (eds). Communication and Citizenship: Journalists and the Public Sphere in the New Media Age. London: Routledge.

— . 1991b. 'Mass Media and Democracy: A Reppraisal'. In J Curran \& M Gutrevich (eds). Mass Media and Democracy. London: Edward Arnold.

Keane, J. 1992 Media and Democracy. London: Polity Press.

Murdoch, G. 1992. 'Citizens, Consumers, and Public Culture'. In M Skovmand \& K Schroeder (eds). Media and Culture: Reappraising Transnational Media.

Ndegwa, S N. 1996. The Two Faces of Civil Society: NGOs and Politics in Africa.

West Hartford: Kuruman Press.

Osaghae, E. 1997. 'The Role of Civil Society in Democracy'. Africa Insight.

Ronning, H. 1993 'Media and Democracy: A Discussion of Theories and

Principles'. In H Arnsten (ed). Media, Culture and Development. Oslo: Oslo University Press.

SADC-PF. 2001. SADC Parliamentary Forum: Norms and Standards for Elections in the SADC Region. Windhoek: SADC Parliamentary Forum. 
Selinyane, N P. 1997a. Lesotho's Palace Coup of July 1997. National University of Lesotho (Mimeo).

1997b. 'Civil Society and the Retrieval of Electoral Politics in Lesotho'. Lesotho Social Science Review 3(2). 